\title{
The nanobiocomposites synthesis from biomass and its characterization
}

\author{
Yapıncak Göncü ${ }^{1}$, Emir Zafer Hoşgün², Nuran Ay ${ }^{3 *}$, Berrin Bozan ${ }^{4}$ \\ 'BORTEK Boron Technologies and Mechatronic Inc., OSB, Eskişehir, Turkey; ORCID ID orcd.org/0000-0002-8602-9765 \\ ${ }^{2}$ Department of Chemical Engineering, Anadolu University, Eskişehir, Turkey; ORCID ID orcd.org/0000-0002-3810-701X \\ ${ }^{3}$ Department of Material Science and Engineering, Anadolu University, Eskişehir, Turkey; ORCID ID orcd.org/0000-0002-2228-9904 \\ ${ }^{4}$ Department of Chemical Engineering, Anadolu University, Eskişehir, Turkey; ORCID ID orcd.org/ 0000-0002-3112-5784
}

\section{ARTICLE INFO}

Article history:

Received 09 January 2018

Received in revised form 03 April 2018

Accepted 12 April 2018

Available online 05 July 2018

Research Article

DOI: 10.30728/boron.376517

\section{Keywords:}

Biomass,

Boron nitride,

Cellulose,

Lignocellulose;

Nanobiocomposite

\begin{abstract}
This study was conducted to evaluate the suitability of using hexagonal boron nitride $(\mathrm{hBN})$ as reinforcement in natural fibres obtained from hazelnut shell $(\mathrm{F})$ and poppy straw $(\mathrm{H})$. Raw materials were treated with alkali to enrich the cellulose content by removing lignin and hemicellulose. The nanobiocomposite synthesis was performed with $4 \%$ and $8 \%$ of hBN. Lignin, cellulose and hemicelluloses contents of biomass were determined. Cellulose content was almost increased 3-fold and 2-fold after pretreatment of hazelnut shell (FCell) and poppy straw (HCell), respectively. Strong bands at 812 and $1380 \mathrm{~cm}^{-1}$ corresponding to $\mathrm{hBN}$ were observed in the FTIR. SEM images showed that $\mathrm{hBN}$ is retained on the pretreated natural fibres. Adsorbed hBN on the structure was highest in the microcrystalline cellulose (Cell) $(91.5 \%)$, followed by FCell $(80.5 \%)$ and HCell (50.5\%). Nanobiocomposites containing lignocellulose and hBN may be recommended for use in polymer matrix structures where thermal properties need to be altered.
\end{abstract}

\section{Introduction}

Recent technological developments for fabrication of biopolymers have been attracted the attention of polymer industry due to the potential to substitute petroleum-based polymers. Biopolymers are biomassderived renewable polymers which are cellulose, chitosan etc. The use of cellulose or lignocelluloses, carbon nanofibers, carbon nanotubes (CNT) and nanoclay materials as fillers or reinforcements for polymeric matrices has become increasingly important because of their abundance, biodegradability, low cost and renewability $[1,2]$. These types of materials also known as "green composites" are promising for the next generation due to the environmentally friendly and renewable $[3,4]$. Lignocellulosic materials exhibit attractive properties in the biodegradable matrices such as low density, low cost, abundance, renewability, and biodegradability [5].

Lignocelluloses consist of cellulose, hemicellulose, and lignin. Cellulose is a linear polymer composed of $\beta$-D-glucopyranose (glucose) units forming microfibrils that give strength and resistance to the cell wall. Hemicelluloses consist of variety of polysaccharides, which are interspersed with the microfibrils of cellulose [6]. Lignins are highly complex polyphenolic biopolymers with aromatic units in different configurations. Composites reinforced with lignocellulose can be improved by surface or structural modification of the fibers using various processes such as alkali treatment, bleaching, acetylation and steaming [7-9].

The studies investigating the suitability of natural reinforced components such as flax, cotton [10], jute [11], ramie [7], oil palm, hemp [12,13], cellulose [14] are available in the literature. Although, the use of natural fiber in polymeric matrices and biocomposites is a beneficial strength, there are also disadvantages such as a tendency to absorb moisture, poor wettability and adhesion with synthetic counterparts and low thermal stability during processing $[15,16]$. Therefore, in order to increase chemical and thermal properties of natural fibers, some chemicals are used such as, maleic anhydride acetic anhydride, silane and styrene [17-20]. Similarly, nanoparticles such as nanoclay [21], BNNTs [22], CNTs [23], and graphene nanosheets [24] are used as a filler with the aim to improving the biodegradation rate, the mechanical properties and electrical conductivity of polymer matrix [25].

Hexagonal boron nitride ( $\mathrm{hBN}$ ) is a synthetic material with a layered crystal structure that has strong covalent bonds between atoms in basal plane but weak Van der Waals bonds between layers. hBN is also known as "white graphite" has similar hexagonal crystal structure as of graphite and it has many unique novel properties like high thermal conductivity, high 
thermal stability, electrically insulation, chemical inertness, resistance to oxidation and molten metals and lubricating effect $[26,27]$. It is also used in cosmetic and medical applications because of its biocompatible and nontoxic behavior [28].

There are several studies in the literature that nano hexagonal boron nitride used as a filler in the polymerbased composites [3,29-32]. Swain et al. have prepared nanobiocomposite using cellulose nanofibrils filled with different percentage of hexagonal boron nitride, and they have reported that thermal stability, oxygen barrier property and chemical resistance of the nanobiocomposites filled with hBN was higher than those of virgin cellulose [3]. Suleiman et al. studied the characterization of CNF-BN nanocomposite by FTIR, SEM, and showed that thermal conductivity of cellulose was increased with hBN [33]. In the other study, nanocomposite paper filled with hexagonal boron nitride nanosheets (BNNSs) and nanofibrilated cellulose has reported possessing high thermal and mechanical properties [34]. The similar effect was reported in the cellulose/hexagonal boron nitride coreshell spherical microbeads by Nagaoka et al [35]. However, in all these studies, microcrystalline cellulose was used as natural fiber. Therefore, we aimed in this study, synthesis and characterization of nanobiocomposites contains nano hBN and lignocellulose obtained two different agricultural wastes (hazelnut shells and poppy stalks) were investigated.

\section{Material and methods}

The nano hBN powders (D50: $0.121 \mu \mathrm{m}$ ) used in the present work were supplied from BORTEK, Boron Technologies and Mechatronics Inc., Turkey. Two types of agricultural biomass (hazelnut shells $(F)$ and poppy stalks $(\mathrm{H})$ ) were used for nanobiocomposite preparation. Hazelnut shells were purchased from Besikduzu, Trabzon in the Blacksea region, whereas poppy stalks were kindly provided by Afyon Alkaloids Factory, Bolvadin, Turkey. The air dried materials were grounded and then screened to obtain particle sizes between $0.224-0.850 \mathrm{~mm}$. Microcrystalline cellulose was purchased from Sigma-Aldrich. $\mathrm{NaOH}$ and $\mathrm{H}_{2} \mathrm{SO}_{4}$ used in this study were analytical grads. Double distilled water was used in all experiments.

\subsection{Preperation of natural fibres}

Poppy stalks were pretreated with $2 \%$ of $\mathrm{NaOH}$ at $90^{\circ} \mathrm{C}$ for $60 \mathrm{~min}$, and hazelnut shells treated with $5 \%$ of $\mathrm{NaOH}$ at $180^{\circ} \mathrm{C}$ for $30 \mathrm{~min}$. All pretreated biomasses were filtered for the solid recovery and washed with distilled water until the wash water turns to $\mathrm{pH} 7.0$, dried to $9-10 \%$ moisture, and then used as the matrix for nanobiocomposite preparation. The chemical composition of raw and pretreated biomass was determined according to NREL methods [36,37]. $0.3 \mathrm{~g}$ solid was hydrolyzed by $3 \mathrm{~mL}$ of $72 \%(\mathrm{w} / \mathrm{w}) \mathrm{H}_{2} \mathrm{SO}_{4}$ at $30{ }^{\circ} \mathrm{C}$ for 60 minutes then, the reaction mixture was diluted to $4 \%(\mathrm{w} / \mathrm{w})$ and autoclaved at $121^{\circ} \mathrm{C}$ for 60 minutes. Lignin was determined by solid residue, cellulose and hemicellulose amount were determined from the filtrate by using High-Performance Liquid Chromatography (Agilent 1100 HPLC system). The HPLC system was mainly equipped with a Bio-Rad Aminex HPX-87P column $(300 \mathrm{~mm} \times 7.8 \mathrm{~mm})$, and a refractive index detector. The analytical column was operated at $80^{\circ} \mathrm{C}$ with $0.2 \mu \mathrm{m}$ filtered HPLC grade water as the mobile phase. The mobile phase flow rate was $0.6 \mathrm{~mL} / \mathrm{min}$.

\subsection{Preparation of lignocellulose-hBN nanobiocomposite}

Microcrystalline cellulose and lignocellulose-hBN nanobiocomposites were prepared by simple solution method with the variable percentage of nano hBN [3]. First, pretreated biomass $(2.5 \mathrm{~g})$ was dispersed in water by magnetic stirred at about $500 \mathrm{rpm}$ for $30 \mathrm{~min}$ at $60^{\circ} \mathrm{C}$ and followed by treatment with Sonic and Materials Inc. VCX750, 20kHz ultrasonic homogenizer for 30 $\min$ at $60^{\circ} \mathrm{C}$. Then, different amounts of nano hBN (4 $w t \%$ and $8 w t \%$ ) were added to the solution. The slurry was magnetic stirred further $30 \mathrm{~min}$ and sonicated for $30 \mathrm{~min}$ at $60^{\circ} \mathrm{C}$. The resulting nanobiocomposite suspension was continued stirring for $3 \mathrm{~h}$ at $60{ }^{\circ} \mathrm{C}$ to get a viscous solution. The final viscous solution was kept overnight and filtered under vacuum. The solid residue was dried in an oven at $50{ }^{\circ} \mathrm{C}$ for $24 \mathrm{~h}$. The dried sample was ground in an agate mortar and stored for analysis. The lignocellulose-hBN samples are coded as in Table 1. Solution remained after vacuum filtration was centrifuged at 8000rpm (NÜVE-NF1200), then solid residue was dried in an oven at $80{ }^{\circ} \mathrm{C}$ (MMM Ecocell) and was weighted to determine the amount of nano hBN unattached to biomass.

Table 1. Ligncellulose-hBN nano composite sample codes.

\begin{tabular}{ccc}
\hline Materials & $\begin{array}{c}\text { hBN } \\
(\%)\end{array}$ & \multicolumn{1}{c}{ Code } \\
\hline \multirow{3}{*}{ Cellulose } & 0 & Cell \\
& 4 & Cell4hBN \\
& 8 & Cell8hBN \\
Hazelnut & 0 & FCell \\
shells & 4 & FCell4hBN \\
& 8 & FCell8hBN \\
Poppy & 0 & HCell \\
stalks & 4 & HCell4hBN \\
& 8 & HCell8hBN \\
\hline
\end{tabular}

\subsection{Characterization of lignocellulose-hBN nanobiocomposites}

The phase compositions of raw materials and the composites were determined by using Rigaku Rint 2000 X-ray diffractometer with CuKa radiation $(\lambda=1.5418 \AA)$, in the $2 \theta$ range of $10-70^{\circ}$ with the scan speed of $2 \%$ min. The chemical interactions of lignocelluloses and nano hBN were studied by a Fourier transform infrared spectroscopy (FTIR, Perkin-Elmer Frontier) in the 
range of $4000-600 \mathrm{~cm}^{-1}$. The thermogravimetric analysis (TGA) of the prepared samples were performed on a NETZSCH STA409 PC/PG instrument, from room temperature to $800{ }^{\circ} \mathrm{C}$ at a heating rate of $10{ }^{\circ} \mathrm{C} \mathrm{min} \mathrm{m}^{-1}$ under nitrogen atmosphere. The microstructure of the pretreated biomasses and lignocellulose-hBN nanobiocomposites were examined by means of scanning electron microscopy (SEM, ZEISS SUPRA 50VP).

\section{Results and discussion}

\subsection{The characterization of biomass material}

The chemical composition of raw and pretreated biomass is shown in Table 2. Lignin was abundant in raw hazelnut shells (51.1\%). After alkali pretreatment, 47\% of lignin was removed and cellulose content increased almost three-fold up to $48 \%$. Cellulose content was $41 \%$ in the pretreated poppy stalks. The major effect of alkaline pretreatment is believed to be dissolution of lignin and hemicellulose, and saponification (de-esterification) of intermolecular ester bonds [5,38]. FCell showed a higher ratio of hemicellulose/lignin $(\mathrm{H} / \mathrm{L})$ than that of HCell.

Table 2. The percent of cellulose $(\mathrm{C})$, hemicellulose $(\mathrm{H})$ and lignin (L) content of raw and pretreated biomass.

\begin{tabular}{cccccc}
\hline Materials & $\begin{array}{c}\mathbf{C} \\
\mathbf{( \% )}\end{array}$ & $\begin{array}{c}\mathbf{H} \\
\mathbf{( \% )}\end{array}$ & $\begin{array}{c}\mathbf{L} \\
\mathbf{( \% )}\end{array}$ & $\mathbf{H / L}$ & $\begin{array}{c}\text { Total } \\
\text { Residue } \\
(\%)\end{array}$ \\
\hline Raw F & 16.7 & 13.3 & 51.1 & 0.260 & 18.9 \\
FCell & 48.4 & 16.3 & 27.3 & 0.597 & 8 \\
Raw H & 24.4 & 20.5 & 19.8 & 1.035 & 35.3 \\
HCell & 41.0 & 9.4 & 19.3 & 0.487 & 30.3 \\
\hline
\end{tabular}

FTIR spectra of Cell, FCell, HCell are shown in Figure 1. In the spectrum of microcrystalline cellulose, the absorbance at 3352, 2917, 1648, 1435, 1375, 1342, 1312, 1288, 1210, 1166, 1109, 1085, 1033, 1000, 893 $\mathrm{cm}^{-1}$ were associated with cellulose [39]. All samples consist of a broad band at $3600-3200 \mathrm{~cm}^{-1}$ due to $\mathrm{O}-\mathrm{H}$ stretching. The band at $2938 \mathrm{~cm}^{-1}$ is the $\mathrm{C}-\mathrm{H}$ stretching deformation of $\mathrm{CH}_{3}$, and $\mathrm{CH}_{2}$. The band at 1645 $\mathrm{cm}^{-1}$ which is associated the $\mathrm{OH}$ bending vibrations is variable in its intensity for FCell and HCell [40]. In addition, the absorption band at $1430 \mathrm{~cm}^{-1}$, indicates to a symmetric $\mathrm{CH}_{2}$ bending vibration, known as "crystallinity band" [41]. An increasing in its intensity means increment in the degree of crystallinity of samples. The peak at $898 \mathrm{~cm}^{-1}$ indicates the purity of the cellulose, which resulted from $\mathrm{C}-\mathrm{H}$ vibration [42]. An increase in its intensity occurring in the pretreated biomass means that the structure is partially amorphous. The presence of a strong band centered at $1745 \mathrm{~cm}^{-1}$ in the fingerprint region, attributed to stretching vibrations of the $\mathrm{C}=\mathrm{O}$ bond in the acetyl group in the hemicelluloses [43]. Compared with the Cell, there is no big differences was found in the fingerprint region of FCell and HCell. Spectrum bands at $1502 \mathrm{~cm}^{-1}$ and $1250 \mathrm{~cm}^{-1}$ for FCell and $\mathrm{HCell}$ were indicated an aromatic ring vibration [44-46]. This was a clear evidence of remained lignin in the structure even if alkali pretreated.

\subsection{Microstructure results}

Figure 2 shows the microstructure of microcrystalline cellulose and pretreated lignocellulose samples taken at the same magnification. Microcrystalline cellulose shows the fibers with diameters of 10 to $20 \mu \mathrm{m}$ and length of 50 to $150 \mu \mathrm{m}$ (Figure 2a). The pretreatment process affected biomass structures differently and led to the formation of the structural differences between them. The pretreated samples seem to be in the form of agglomerates and the SEM images indicate that pretreatments increase the roughness. This might indicate that a partial removal of the noncellulosic layer. FCell consists of regular microstructure having pores 80-100 $\mu \mathrm{m}$ (Figure 2b). HCell structure seems to be strongly damaged after alkali pretreatment (Figure 2c). The rough surface may be preferred as it increases adhesion in the composite matrix [47].

\subsection{The characterization of lignocellulose-hBN nanobiocomposite}

The FTIR spectra of nanobiocomposites filled with hBN are shown in Figure 3. Boron nitride has a strong band at 795 and $1380 \mathrm{~cm}^{-1}$ corresponding to B-N-B and $\mathrm{B}-\mathrm{N}$ bond, respectively $[48,49]$. These bands are present around the same position in the fingerprint

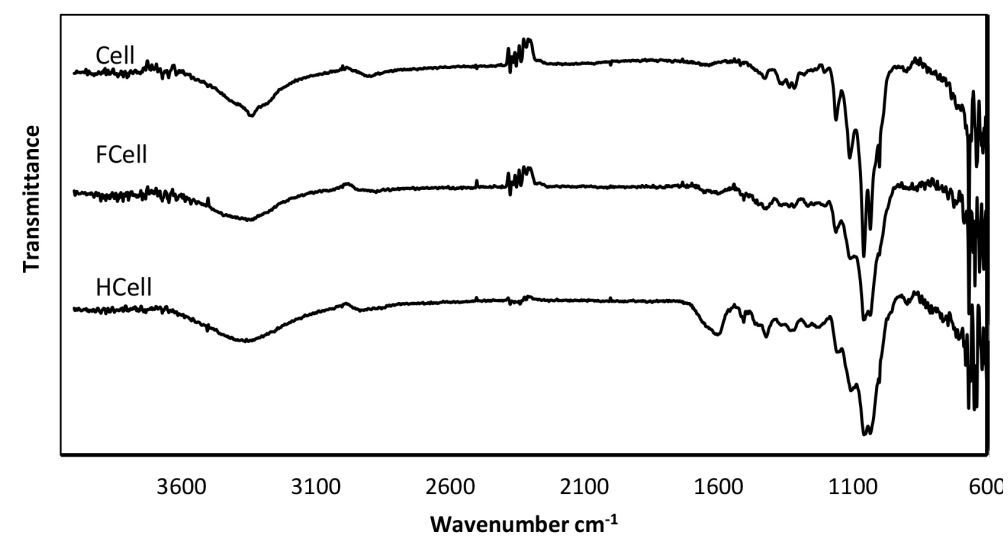

Figure 1.FTIR spectra of microcrystalline cellulose (Cell), pretreated hazelnut shell (FCell), poppy straws (HCell). 


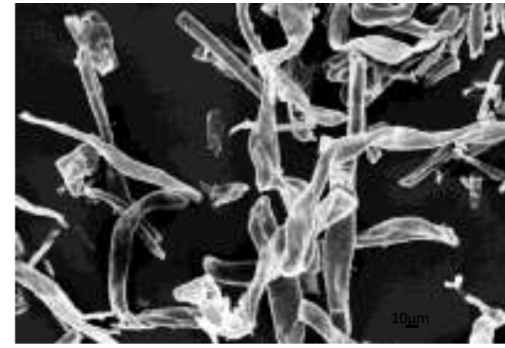

(a)

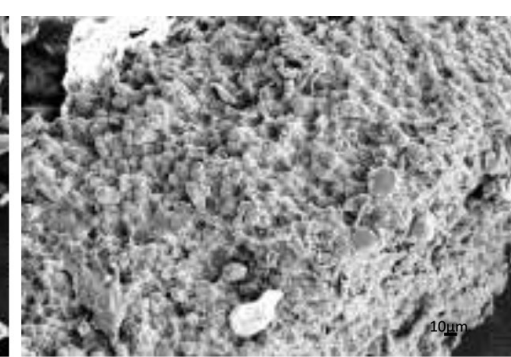

(b)

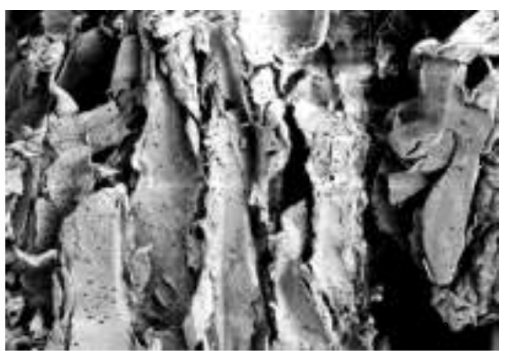

(c)

Figure 2.SEM images of (a) Cell, (b) FCell, (c) HCell.

regions of all spectra indicating the formation of nanobiocomposite. The band at $3400 \mathrm{~cm}^{-1}$ increases with increasing amount of boron nitride. It can be attributed to moisture absorbed during preparation.

In order to investigate the structural morphologies of the nanobiocomposites, the microstructure of samples is analyzed and shown in Figure 4. These images clearly show that hBN is adsorbed on the pretreated natural fibers. The mechanism of the adsorption of $\mathrm{hBN}$ nanoparticles on the lignocellulosic samples is attributed to hydrogen bonding between $\mathrm{OH}$ groups in lignocellulose and the defective edge of BN [50]. The presence both polar $-\mathrm{OH}$ groups and hydrophobic $\mathrm{CH}$ moieties in the lignocellulose-hBN biocomposite allows lignocellulose to be used as dispersant.

To determine the adsorbed hBN on the lignocellulosic biomass, the amount of residual hBN in the solution after synthesis of lignocellulose-hBN nanobiocomposite using $4 \%$ of hBN was determined gravimetrically. The amount of $\mathrm{hBN}$ was highest in the Cell (91.5\%), followed by FCell ( $80.5 \%$ ) and HCell (50.5\%). According to chemical analysis (Table 2), the total amount of hemicellulose and cellulose (Holocellulose) was found to be higher on FCell than on HCell. Although there is insufficient information about the mechanism of adsorption, the adsorption of $\mathrm{hBN}$ may attribute to the cellulose and hemicellulose content in the pretreated biomass.

X-ray diffraction analysis results of the nanobiocomposites samples are shown Figure 5 . The three well defined crystalline peaks at $15.7^{\circ}, 22^{\circ}$ and $34.5^{\circ}$ were belonging to cellulose (JCPDS Card No:00-056-1718). The sharp peak at $26.0^{\circ}$ identified to crystalline hexagonal boron nitride (JCDPS Card No: 00-034-0421). The difference between XRD results of all samples was caused by the different amount of cellulose present in the biomass samples as shown Table 2. Since, the increase in the crystallinity is the increased the material strength [51], the degree of crystallinity $(\mathrm{Crl})$ was calculated according to Eq. 1 [52],

$$
\operatorname{CrI}(\%)=\frac{I_{(002)}-I_{(\text {amorphous })}}{I_{(002)}} * 100
$$

where $\mathrm{I}_{(002)}$ is the maximum intensity at a diffraction angle $22^{\circ}$ attributed to crystalline regions and
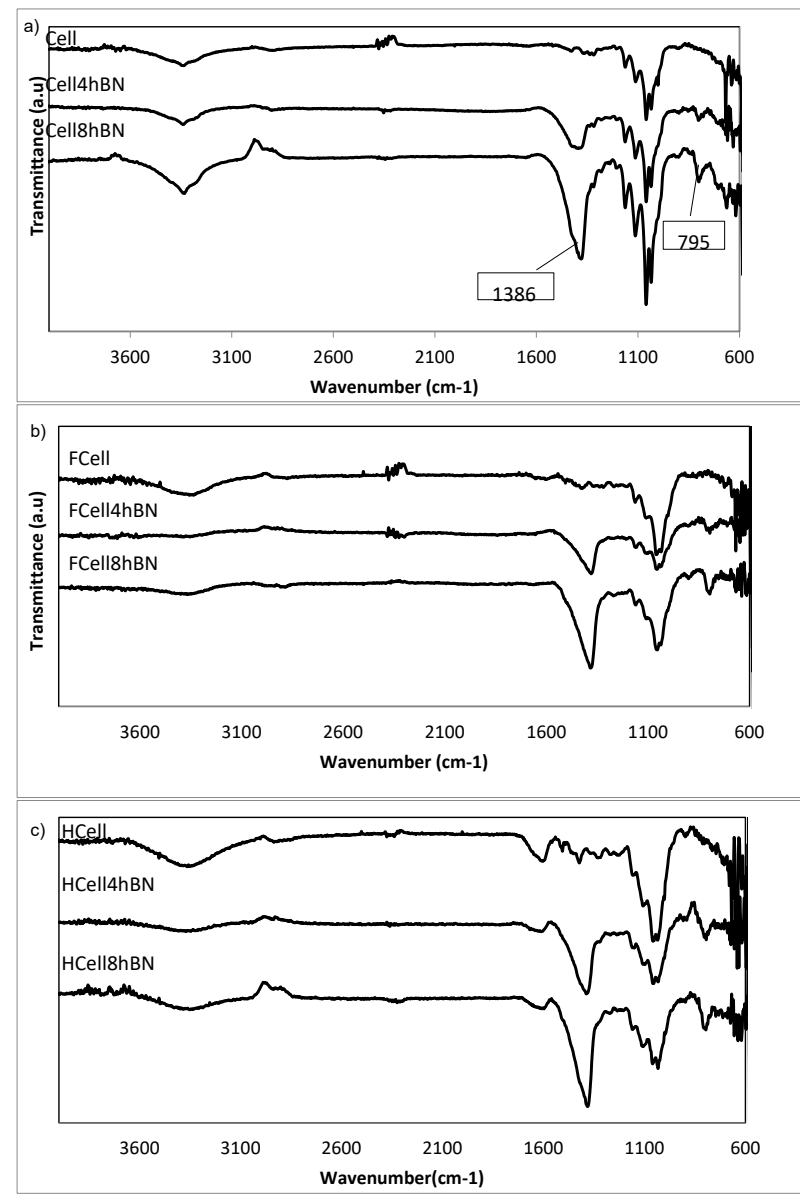

Figure 3. FTIR spectra of a) Cell nanobiocomposites b) FCell nanobiocomposites and c) HCell nanobiocomposites.

$\mathrm{I}_{\text {amorphous }}$ is the intensity diffraction at $2 \theta \approx 18^{\circ}$, attributed to amorphous regions. Segal's equation was used as comparison purpose. The results are summarized in Table 3. As expected, highest crystallinity was in cellulose samples followed by FCell and HCell.

Table 3. Crystallinity index (Crl) of nanobiocomposites.

\begin{tabular}{cc}
\hline Sample Name & Crl (\%) \\
\hline Cell4hBN & 84.87 \\
Cell8hBN & 82.26 \\
FCell4hBN & 57.67 \\
FCell8hBN & 58.09 \\
HCell4hBN & 51.57 \\
HCell8hBN & 58.68 \\
\hline
\end{tabular}

TGA was carried out to understand the effect of boron nitride on the thermal property of the Cell, FCell, HCell, 


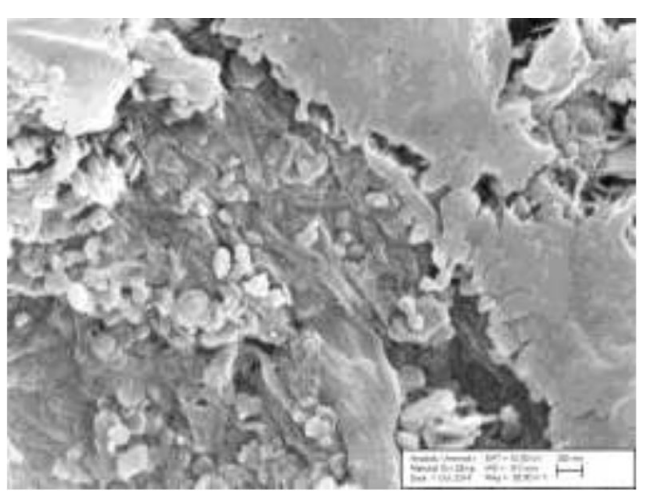

a) Cell $4 \mathrm{hBN}$

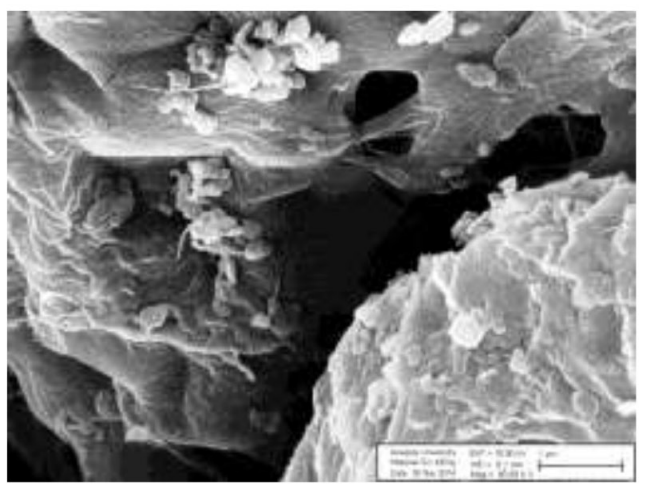

c) FCell4hBN

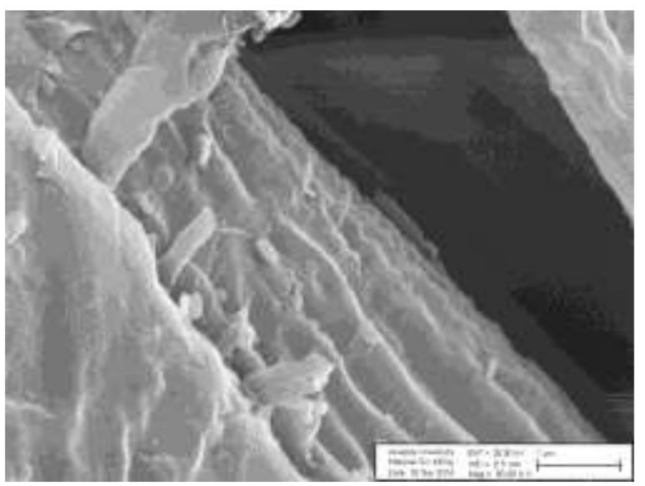

g) HCell4hBN

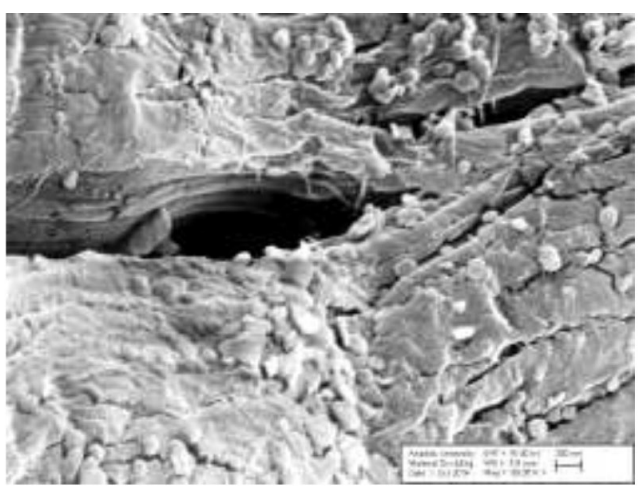

b) Cell8hBN

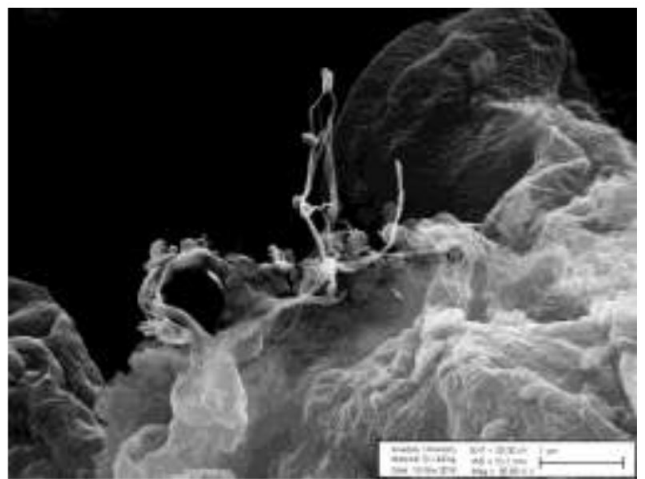

d) FCell8hBN

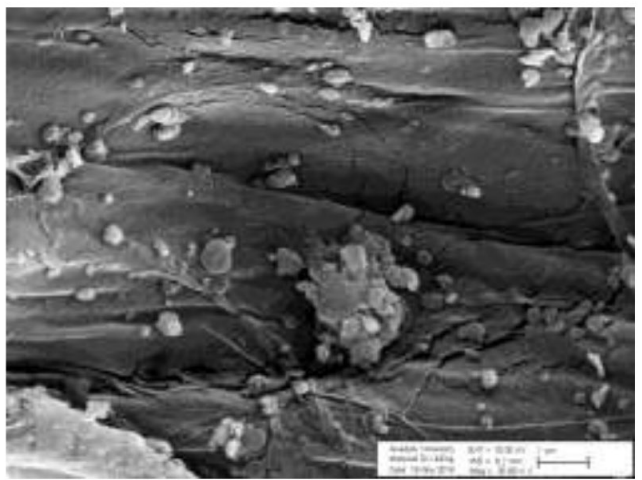

h) HCell8hBN

Figure 4. SEM images of nanobiocomposites samples.

and the nanobiocomposite samples in the temperature range $20-800{ }^{\circ} \mathrm{C}$. The thermograms of samples are shown in Figure 6a. Initial weight loss was observed in all samples due to the removal of moisture when the samples were heated up $130{ }^{\circ} \mathrm{C}$. HCell and FCell in this stage showed a higher perceived weight loss than the Cell. It can be said that FCell and HCell had more adsorbed water than the Cell. In the second weight loss, we observed that Cell had a higher stability up to $270{ }^{\circ} \mathrm{C}$ than the FCell and HCell. The reason for high thermal stability of cellulose might be explained with its good order structure which consists of a long polymer of glucose without any branches. There was a sharp weight loss for Cell from 270 to $382{ }^{\circ} \mathrm{C}$ and it had the maximum mass loss rate $(30.1 \% / \mathrm{min})$ at $351{ }^{\circ} \mathrm{C}$. The second weight loss mainly happened at $234-359{ }^{\circ} \mathrm{C}$ for FCell and $215-387^{\circ} \mathrm{C}$ for HCell. Onset temperature of samples were shown differences and the maximum mass loss rates determined $9.11 \% / \mathrm{min}$ at $328{ }^{\circ} \mathrm{C}$ and $10.0 \% / \mathrm{min}$ at $350^{\circ} \mathrm{C}$, respectively as seen Figure $6 \mathrm{~b}$. The hemicellulose/lignin ratio in the sample causes this difference in maximum loss rates [53]. From the data given in Table 2, $\mathrm{H} / \mathrm{L}$ ratio was found to be 0.597 in the FCell sample and 0.487 in the HCell sample. The hemicellulose consists of various saccharides such as xylose, mannose, glucose, galactose, etc. It shows an amorphous structure, rich of branches which are very easy to decompose. Different to hemicellulose, lignin shows the aromatic rings with various branches that it possesses provide degradation over a wider temperature range [39]. The lignin and hemicellulose contents in the structure of the lignocelluloses decrease the degradation rate of the structure increases. Similar to Nair and Yan [54], we found that the rate of thermal 

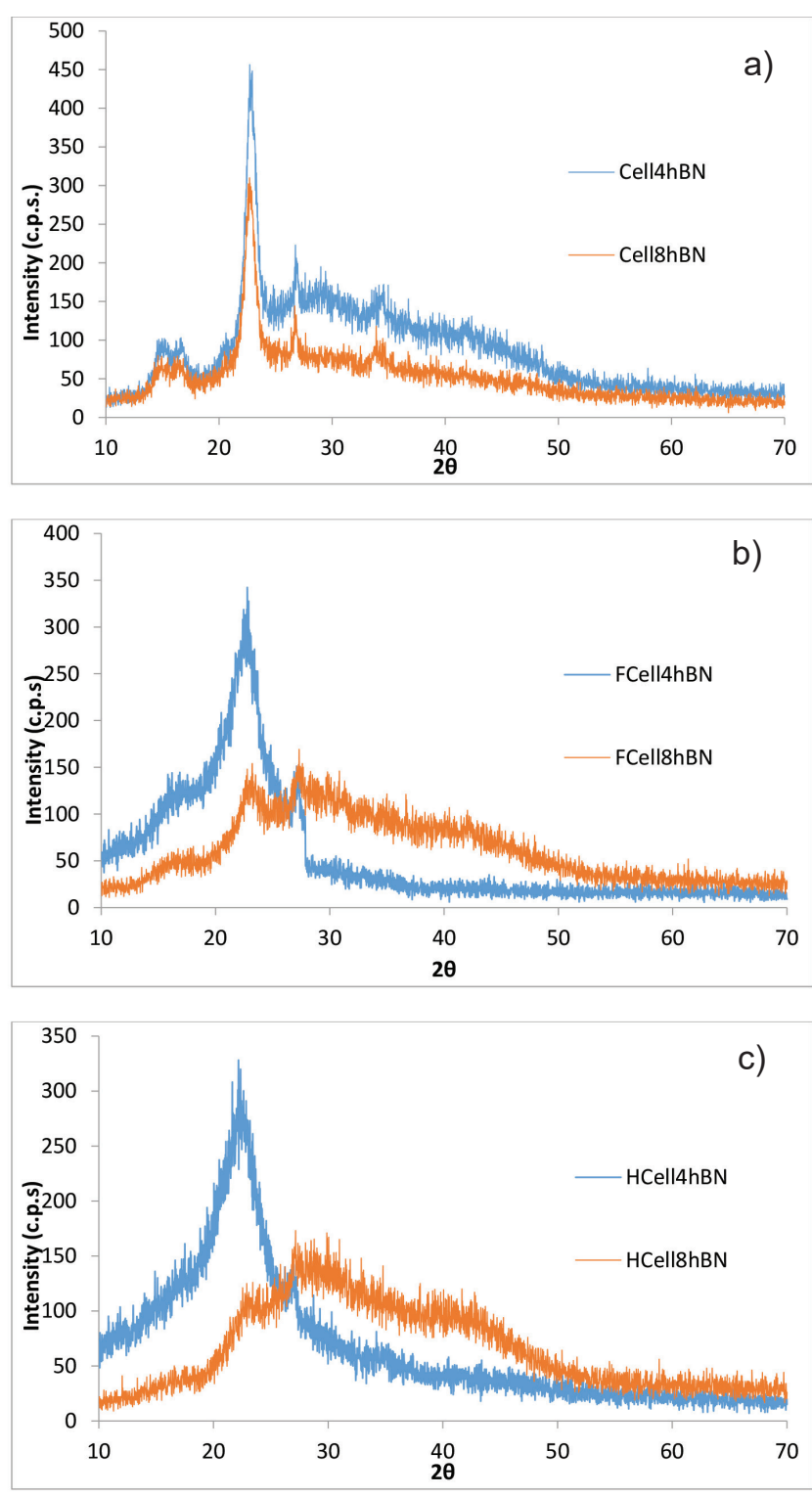

Figure 5. XRD analysis of nanobiocomposite samples.

degradation decreases with increasing amount of lignin in the structure. The last stage of weight loss was explained with the combustion of volatiles and formation of char residue. We could note that the differences between total mass losses are related to the residual content of samples.

The DTA curves of samples are corresponded well with their DTG data (Figure 6c). All samples exhibit an endothermic peak at around $100{ }^{\circ} \mathrm{C}$ due to the evaporation of water. Cell shows an endothermic peak at $351{ }^{\circ} \mathrm{C}$ different from the FCell and HCell in accordance with the literature [39]. FCell exhibit two small exothermic peaks at $345{ }^{\circ} \mathrm{C}$ and $405{ }^{\circ} \mathrm{C}$, similarly, $\mathrm{HCell}$ shows two exothermic reactions at $350{ }^{\circ} \mathrm{C}$ and $400{ }^{\circ} \mathrm{C}$, indicating that their decomposition reactions are exothermic.

The effect of boron nitride on the thermal property of Cell is shown in Figure $7 \mathrm{a}$. The addition of $8 \% \mathrm{hBN}$
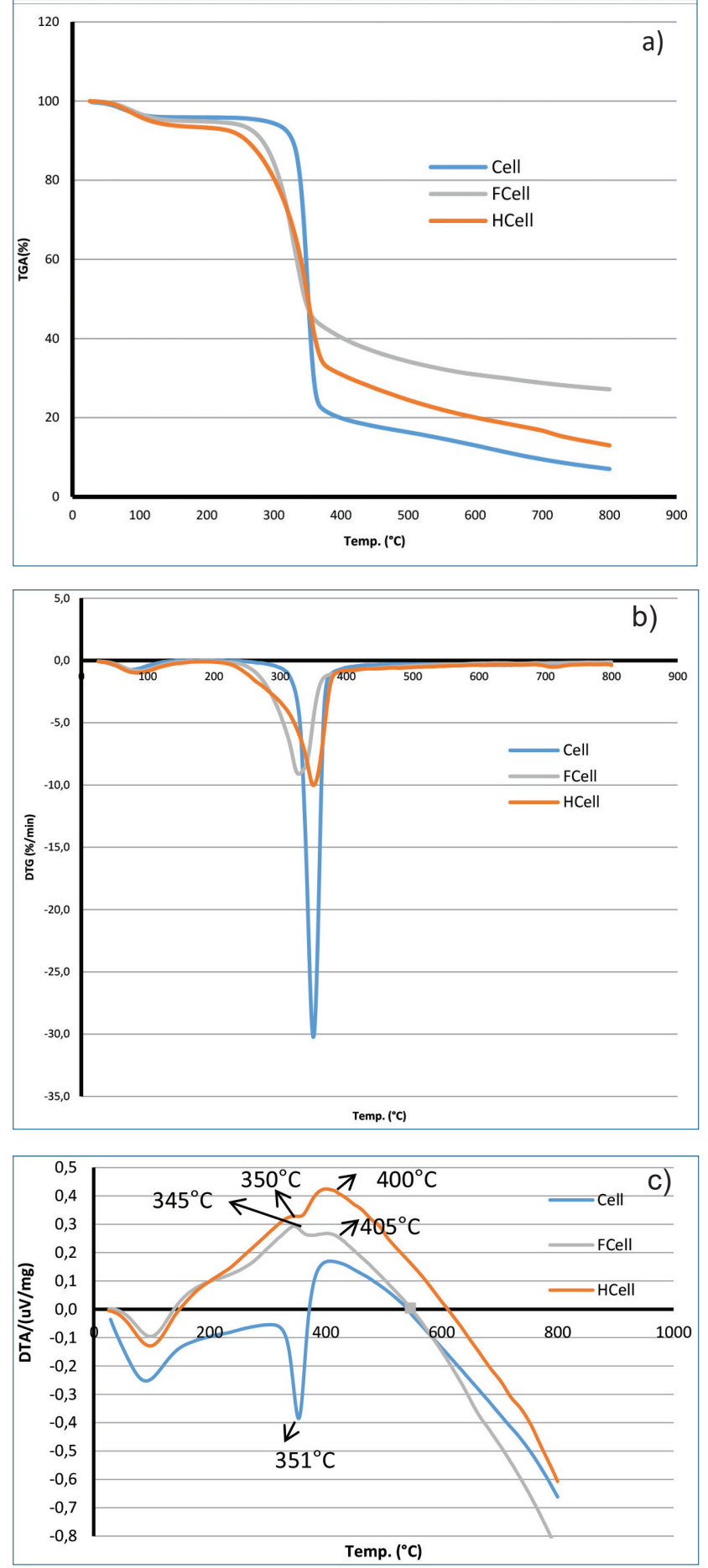

Figure 6. TG, DTA and DTG curves of Cell, FCell and HCell.

increased the thermal stability of Cell from $270{ }^{\circ} \mathrm{C}$ to $275{ }^{\circ} \mathrm{C}$ while the addition of $4 \% \mathrm{hBN}$ did not cause a change in the thermal stability of Cell. The maximum mass loss rates were $30.1 \% / \mathrm{min}$ at $351{ }^{\circ} \mathrm{C}$ for Cell, $25.9 \% / \mathrm{min}$ at $349^{\circ} \mathrm{C}$ for Cell-4hBN and $28.2 \% /$ min at $350{ }^{\circ} \mathrm{C}$ for Cell-8hBN. $8 \%$ hBN addition caused a decrease in the degradation rate of Cell however, hBN addition had no effect on the onset temperature change as seen Figure $7 \mathrm{~b}$.

According to TG/DTA curves for the FCell hBN nanobiocomposites, in all samples, approximately $54 \%$ of 

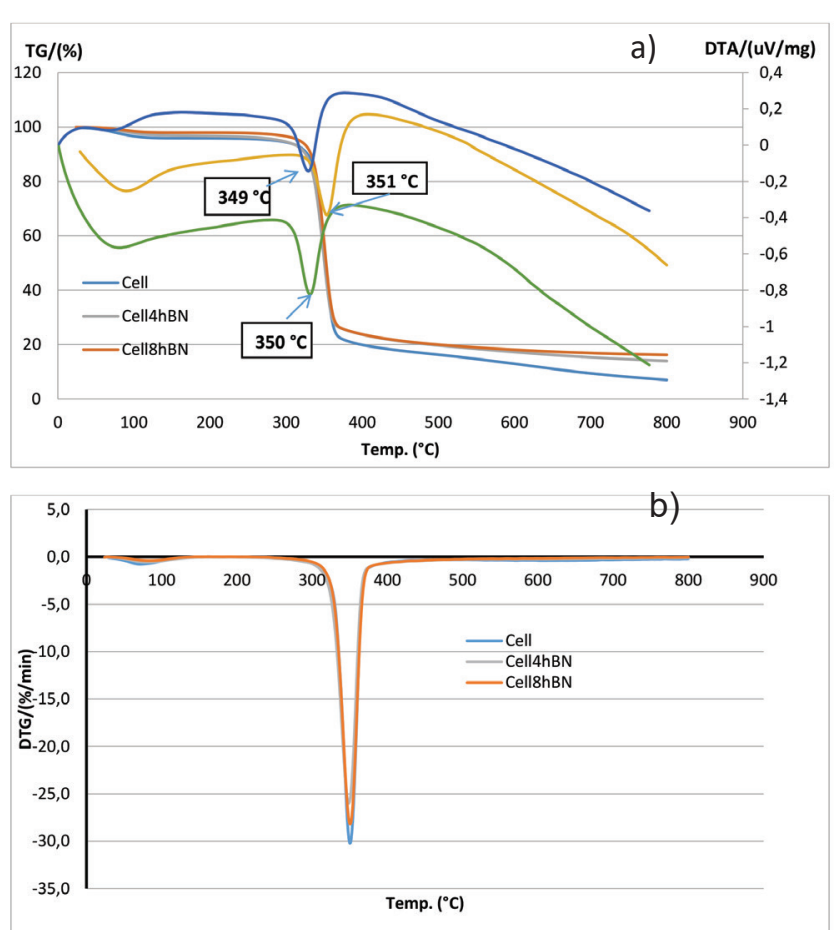

Figure 7. TG, DTA and DTG curves of cellulose hBN nanobiocomposites.

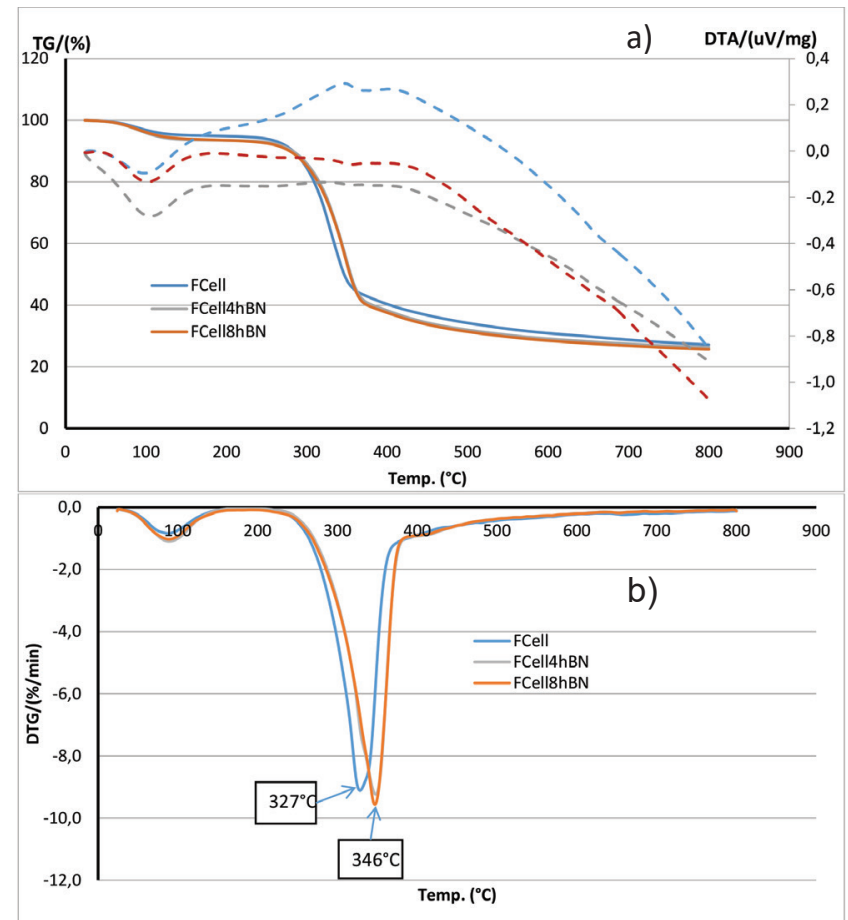

Figure 8. TG, DTA and DTG curves of FCell hBN nanobiocomposites.

the original weight was lost, indicating the decomposition of the polysaccharide molecules. It can be said that exothermic peaks belonging to FCell are suppressed by the addition of hBN as seen Figure $8 \mathrm{a}$. The temperatures where the maximum mass loss rates observed increased by $20^{\circ} \mathrm{C}$ with the addition of hBN, however, hBN did not altered onset temperature (Figure $8 b)$.
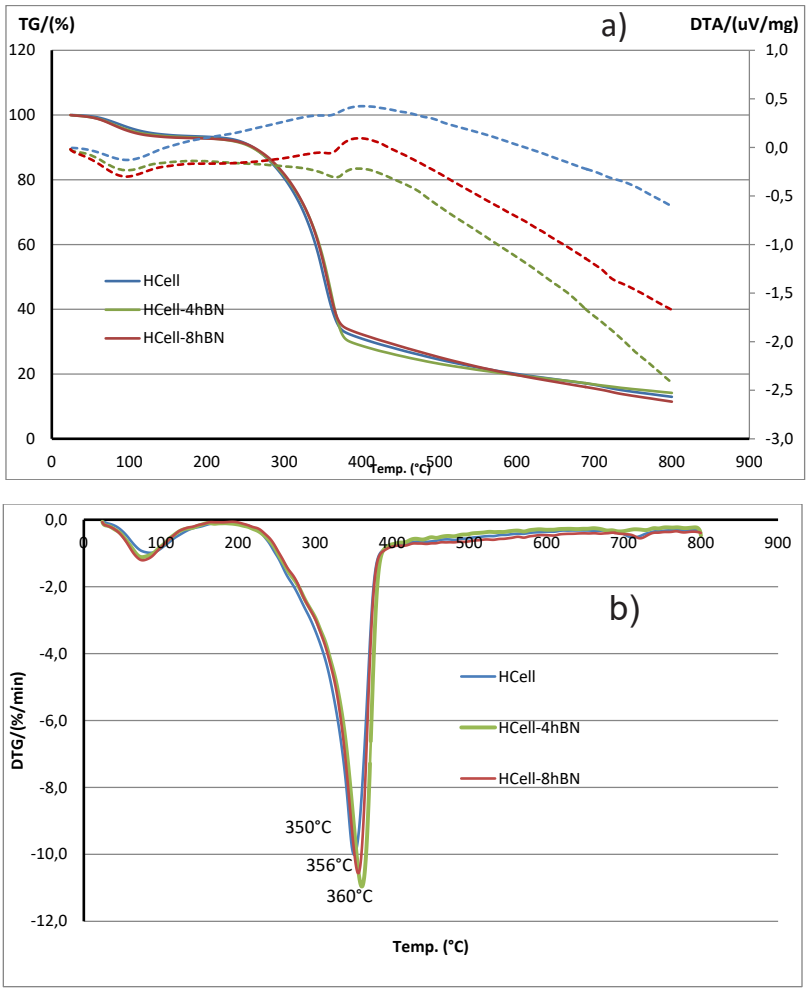

Figure 9. TG, DTA and DTG curves of HCell hBN nanobiocomposites.

The TG curves of HCell nanobiocomposites were almost similar for both $4 \%$ and $8 \% \mathrm{hBN}$ addition, and approximately $65 \%$ of original weight was lost due to the decomposition of the polysaccharide molecules. (Figure 9a). As regards the DTA curves, two exothermic peaks belonging to HCell were suppressed when $\mathrm{hBN}$ added to the structure. Similar behaviour was also observed in the FCell samples. No differences observed at the onset temperatures of all lignocellulose-hBN samples The maximum mass loss rates were $10.0 \% / \mathrm{min}$ at $350^{\circ} \mathrm{C}$ for $\mathrm{HCell}, 10.9 \% / \mathrm{min}$ at 360 ${ }^{\circ} \mathrm{C}$ for HCell4hBN and $10.5 \% / \mathrm{min}$ at $356{ }^{\circ} \mathrm{C}$ for HCell$8 \mathrm{hBN}$ as seen Figure $9 \mathrm{~b}$. The addition of $\mathrm{hBN}$ did not change the thermal properties of HCell. HCell can adsorb $50 \%$ of hBN added at $4 \%$ to its structure. This indicates that increasing the amount of hBN does not cause a change in the amount of hBN adsorbed to the HCell surface.

\section{Conclusions}

In this study, the synthesis and characterization of lignocellulose-hBN nanobiocomposite was investigated. Hazelnut shells and poppy straws were pretreated in order to enriched in holocellulose before using as biocomposite. Microstructural analysis showed that pretreatment process affected biomass structure and led to the formation of the structural differences between them. After pretreatment, the lignocelluloses seem to be in the form of damaged agglomerates having pores, and these structures are thought to increase adhesion in the polymer matrix. Almost $91.5 \%$ of hBN was adsorbed on the cellulose, followed by FCell $(80.5 \%)$ and 
HCell (50.5\%). Although there is insufficient information about the mechanism of adsorption, the adsorption of boron nitride may attribute to the holocellulose content in the pretreated biomass. The degradation reactions of lignocelluloses were exothermic in contrast to that of cellulose. FCell and HCell showed slower degradation rates than that of cellulose, however, they began to degrade at lower temperatures than cellulose. Thermal properties of lignocellulose nanobiocomposites varied depending on the amount of adsorbed hBN. Consequently, this study showed that nanobiocomposites containing lignocellulose and hBN may be used in polymer matrix structures where thermal properties need to be altered.

\section{Acknowledgements}

The authors would like to thank BORTEK Boron Technologies and Mechatronics Inc.

\section{References}

[1] Sanchez-Garcia M. D., Lopez-Rubio A., Lagaron J. M., Natural micro and nanobiocomposites with enhanced barrier properties and novel functionalities for food biopackaging applications, Trends Food Sci. Technol. 21,528-36, 2010.

[2] Hosgun E. Z., Bozan B., Investigation of the effect of low temperature low time alkali pretreatment on hazelnut shells composition and enzymatic hydrolysis, J. Fac. Eng. Archit. Gaz. 32,517-29, 2017.

[3] Swain S. K., Dash S., Behera C., Kisku S. K., Behera L. Cellulose nanobiocomposites with reinforcement of boron nitride: Study of thermal, oxygen barrier and chemical resistant properties, Carbohydr. Polym., 95, 728-32, 2013.

[4] Pandey J. K., Kumar A. P., Misra M., Mohanty A. K., Drzal L. T., Singh R. P., Recent advances in biodegradable nanocomposites, J. Nanosci. Nanotechnol., 5,497-526, 2005.

[5] Tserki V., Matzinos P., Zafeiropoulos N. E., Panayiotou C., Development of biodegradable composites with treated and compatibilized lignocellulosic fibers, J. Appl. Polym. Sci., 100, 4703-10, 2006.

[6] Spiridon I., Popa VI. Chapter 13 - Hemicelluloses: Major Sources, Properties and Applications A2 - Belgacem, Mohamed Naceur. In: Gandini A, editor. Monomers, Polymers and Composites from Renewable Resources. Amsterdam: Elsevier; p. 289-304, 2008.

[7] Pereira P. H. F., Rosa M. dF, Cioffi M. O. H, Benini K. C. C. dC., Milanese A. C., Voorwald H. J. C., et al, Vegetal fibers in polymeric composites: A review,Polímeros, 25,9-22, 2015.

[8] Corradini E., de Morais L., C., de F. Rosa M., Mazzetto S.E., Mattoso L. H. C., Agnelli J. A. M., A Preliminary Study for the Use of Natural Fibers as Reinforcement in Starch-Gluten-Glycerol Matrix, Macromolecular Symposia. 245-246, 558-64, 2006.

[9] Das S., Saha A. K., Choudhury P. K., Basak R. K., Mitra B. C., Todd T., et al. Effect of steam pretreatment of jute fiber on dimensional stability of jute composite. J. Appl. Polym. Sci., 76,1652-61, 2000.

[10] Jiang L., Hinrichsen G., Flax and cotton fiber reinforced biodegradable polyester amide composites, 1. Manufacture of composites and characterization of their mechanical properties, Die Angewandte Makromolekulare Chemie, 268,13-7, 1999.

[11] Plackett D., Løgstrup Andersen T., Batsberg Pedersen W., Nielsen L., Biodegradable composites based on Ipolylactide and jute fibres, Compos. Sci. Technol., 63, 1287-96, 2003

[12] Mohanty A. K., Wibowo A., Misra M., Drzal L. T., Effect of process engineering on the performance of natural fiber reinforced cellulose acetate biocomposites, Composites Part A, 35, 363-70, 2004.

[13] Bodros E., Pillin I., Montrelay N., Baley C., Could biopolymers reinforced by randomly scattered flax fibre be used in structural applications? Compos. Sci. Technol., 67, 462-70, 2007.

[14] Puglia D., Tomassucci A., Kenny J.M., Processing, properties and stability of biodegradable composites based on Mater-Bi® and cellulose fibres, Polym. Adv. Technol., 14, 749-56, 2003.

[15] Shinoj S., Visvanathan R., Panigrahi S., Kochubabu M., Oil palm fiber (OPF) and its composites: A review, Ind. Crops Prod., 33, 7-22, 2011.

[16] Son J., Kim H. J., Lee P. W., Role of paper sludge particle size and extrusion temperature on performance of paper sludge-thermoplastic polymer composites, J. Appl. Polym. Sci., 82, 2709-18, 2001.

[17] Bessadok A., Marais S., Gouanvé F., Colasse L., Zimmerlin I., Roudesli S., et al. Effect of chemical treatments of Alfa (Stipa tenacissima) fibres on watersorption properties, Compos. Sci. Technol., 67,685-97, 2007.

[18] Abdelmouleh M., Boufi S., Belgacem M. N., Dufresne A., Short natural-fibre reinforced polyethylene and natural rubber composites: Effect of silane coupling agents and fibres loading, Compos. Sci. Technol., 67, 1627-39, 2007.

[19] Gindl W., Zargar-Yaghubi F., Wimmer R., Impregnation of softwood cell walls with melamine-formaldehyde resin, Bioresour. Technol., 87, 325-30, 2003.

[20] Cantero G., Arbelaiz A., Llano-Ponte R., Mondragon I., Effects of fibre treatment on wettability and mechanical behaviour of flax/polypropylene composites, Compos. Sci. Technol., 63, 1247-54, 2003.

[21] Saw S. K., Static and Dynamic Mechanical Analysis of Coir Fiber/Montmorillonite Nanoclay-Filled Novolac/ Epoxy Hybrid Nanocomposites. In: Thakur KV, Thakur KM, editors. Eco-friendly Polymer Nanocomposites: Processing and Properties. New Delhi: Springer India; p. $137-54,2015$.

[22] Biscarat J., Bechelany M., Pochat-Bohatier C., Miele P., Graphene-like BN/gelatin nanobiocomposites for gas barrier applications, Nanoscale, 7,613-8, 2015.

[23] Liu L., Shen Z., Zheng Y., Yi M., Zhang X., Ma S., Boron nitride nanosheets with controlled size and thick- 
ness for enhancing mechanical properties and atomic oxygen erosion resistance, RSC Advances, 4,3772632, 2014.

[24] Veca L. M., Meziani M. J., Wang W., Wang X., Lu F., Zhang P., et al. Carbon nanosheets for polymeric nanocomposites with high thermal conductivity. Adv. Mater., 21, 2088-92, 2009.

[25] Othman S. H., Bio-nanocomposite materials for food packaging applications: types of biopolymer and nano-sized filler, Agric. Agric. Sci. Procedia, 2,296-303, 2014.

[26] Kimura Y., Wakabayashi T., Okada K., Wada T., Nishikawa $\mathrm{H}$., Boron nitride as a lubricant additive, Wear, 232,199-206, 1999.

[27] Eichler J., Lesniak C., Boron nitride (BN) and BN composites for high-temperature applications, J. Eur. Ceram. Soc., 28, 1105-9, 2008.

[28] Fiume M. M., Bergfeld W. F., Belsito D. V., Hill R. A., Klaassen C. D., Liebler D. C., et al. Safety assessment of boron nitride as used in cosmetics, Int. J. toxicol., 34, 53S-60S, 2015.

[29] Kisku S. K., Swain S. K., Synthesis and characterization of chitosan/boron nitride composites, J. Am. Ceram. Soc., 95, 2753-7, 2012.

[30] Chan K., Wong H., Yeung K., Tjong S., Polypropylene biocomposites with boron nitride and nanohydroxyapatite reinforcements, Mater., 8, 992. 2015.

[31] Seyhan A. T., Göncü Y., Durukan O., Akay A., Ay N., Silanization of boron nitride nanosheets (BNNSs) through microfluidization and their use for producing thermally conductive and electrically insulating polymer nanocomposites, J. Solid State Chem. 249, 98107, 2017.

[32] Yuan C., Duan B., Li L., Xie B., Huang M., Luo X., Thermal conductivity of polymer-based composites with magnetic aligned hexagonal boron nitride platelets, ACS Appl. Mater. Interfaces, 7,13000-6, 2015.

[33] Sulaiman H.S., Hua C.C., Zakaria S., Cellulose nanofibrils (CNF) filled boron nitride (BN) nanocomposites, AIP Conference Proceedings, 1678, 040006, 2015.

[34] Zhu H., Li Y., Fang Z., Xu J., Cao F., Wan J., et al. Highly thermally conductive papers with percolative layered boron nitride nanosheets, ACS Nano, 8, 360613, 2014.

[35] Nagaoka S., Jodai T., Kameyama Y., Horikawa M., Shirosaki T., Ryu N., et al. Cellulose/boron nitride coreshell microbeads providing high thermal conductivity for thermally conductive composite sheets, RSC Advances, 6, 33036-42, 2016.

[36] Sluiter A., Hames B., Ruiz R., Scarlata C., Sluiter J., Templeton D., et al. Determination of Structural Carbohydrates and Lignin in Biomass: Laboratory Analytical Procedure (LAP) National Renewable Energy Laboratory, p. $16,2008$.

[37] Sluiter A., Hames B., Ruiz R., Scarlata C., Sluiter J., Templeton D., Determination of Ash in Biomass: Laboratory Analytical Procedure (LAP) National Renewable Energy Laboratory 2008.
[38] Garside P., Wyeth P., Identification of Cellulosic Fibres by FTIR Spectroscopy: Thread and Single Fibre Analysis by Attenuated Total Reflectance, Studies in Conservation, 48, 269-75, 2003.

[39] Yang H., Yan R., Chen H., Lee D. H., Zheng C., Characteristics of hemicellulose, cellulose and lignin pyrolysis, Fuel, 86, 1781-8, 2007.

[40] Yuan T-Q., Xu F., He J., Sun R-C., Structural and physico-chemical characterization of hemicelluloses from ultrasound-assisted extractions of partially delignified fast-growing poplar wood through organic solvent and alkaline solutions, Biotechnol. Adv., 28, 583-93, 2010.

[41] Ciolacu D., Ciolacu F., Popa VI. Amorphous cellulose Structure and characterization, Cellul. Chem. Technol., 45, 13-21, 2011.

[42] Oun A. A., Rhim J-W., Characterization of nanocelluloses isolated from Ushar (Calotropis procera) seed fiber: Effect of isolation method, Mater. Lett., 168, 14650, 2016.

[43] Matějka V., Fu Z., Kukutschová J., Qi S., Jiang S., Zhang $X$., et al. Jute fibers and powderized hazelnut shells as natural fillers in non-asbestos organic nonmetallic friction composites, Mater. Des., 51, 847-53, 2013.

[44] Poletto M., Ornaghi H., Zattera A., Native cellulose: Structure, characterization and thermal properties, Mater., 7, 6105, 2014.

[45] Xu F., Yu J., Tesso T., Dowell F., Wang D., Qualitative and quantitative analysis of lignocellulosic biomass using infrared techniques: A mini-review, Appl. Energy, 104:801-9, 2013.

[46] Aytac Z., Gulmezoglu N., Saglam T., Kulan E. G., Selengil U., Hosgun H. L., Changes in N, K, and Fatty Acid Composition of Black Cumin Seeds Affected by Nitrogen Doses under Supplemental Potassium Application, J Chem-Ny, 2017.

[47] Arsene M-A., Bilba K., Savastano Junior H., Ghavami $\mathrm{K}$., Treatments of non-wood plant fibres used as reinforcement in composite materials, Mater. Res., 16, 903-23, 2013.

[48] Zhang Y., Li M., Gu Y., Wang S., Zhang Z., Preparation of high-content hexagonal boron nitride composite film and characterization of atomic oxygen erosion resistance, Appl. Surf. Sci., 402, 182-91, 2017.

[49] Bakan F., Sezen M., Gecgin M., Goncu Y., Ay N., Structural and Chemical Analysis of Hydroxyapatite (HA)Boron Nitride $(\mathrm{BN})$ Nanocomposites Sintered Under Different Atmospheric Conditions, Microsc. Microanal., 23, 891-9, 2017.

[50] Li Y., Zhu H., Shen F., Wan J., Lacey S., Fang Z., et al. Nanocellulose as green dispersant for two-dimensional energy materials, Nano Energy, 13, 346-54, 2015.

[51] Johar N., Ahmad I., Dufresne A., Extraction, preparation and characterization of cellulose fibres and nanocrystals from rice husk, Ind. Crops Prod., 37, 93-9, 2012.

[52] Segal L., Creely J. J., Martin A. E., Conrad C. M., An Empirical Method for Estimating the Degree of Crystal- 
linity of Native Cellulose Using the X-Ray Diffractometer, Text. Res. J., 29, 786-94, 1959.

[53] Wang S., Luo Z., Pyrolysis of Biomass, Beijing, De Gruyter, 2016.
[54] Hosgun E. Z., Berikten D., Kivanc M., Bozan B., Ethanol production from hazelnut shells through enzymatic saccharification and fermentation by low-temperature alkali pretreatment, Fuel, 196, 280-7, 2017. 